\title{
VERIFICATION OF DETERMINATION OF HYDRAULIC CONDUCTIVITY FOR COARSE SOILS BY EMPIRICAL FORMULAS BASED ON THE DENSITY INDEX
}

\author{
Krystyna Jaśkiewicz ${ }^{\bowtie}$, Tomasz Godlewski \\ Building Structures, Geotechnics and Concrete Department, Building Research Institute, Warsaw, Poland
}

\begin{abstract}
This paper examines the importance of empirical formulas for estimating the hydraulic conductivity of non-cohesive soils, taking into account their compaction. Empirical formulas are often used in practice to quickly and cost-effectively determine hydraulic conductivity of soil. Verification of calculation of this parameter was performed for five formulas taking into account the characteristic diameters of grains and porosity. The results obtained by calculations were compared with the results of laboratory tests performed on soil samples with the same porosity coefficients (at different density index) as assumed in the calculation method. An empirical formula has been proposed to correct the hydraulic conductivity of soils obtained from the Hazen formula by taking into account the density index of a given soil.
\end{abstract}

Key words: filtration, hydraulic conductivity, empirical formulas, density index

\section{INTRODUCTION}

The soil filtration properties are very important in the engineering-geological, geotechnical and hydrogeological assessment of the site. The hydraulic conductivity $(k)$ is a parameter which defines the ability of the soil medium to transport water in it. It depends on such soil characteristics as: graining, porosity, mineral composition, moisture, shape and surface texture of particle, temperature of water (Wiłun, 1982; Head \& Epps, 2011; Zięba, 2016; Jiang et al., 2021). Hydraulic conductivity determines the ability of the soil to pass water subjected to water pressure difference. According to the linear Darcy's law, it expresses the relationship between the hydraulic gradient and the water filtration rate (Myślińska, 1998; Head \& Epps, 2011).

The correct determination of the hydraulic conductivity becomes important when assessing the filtration conditions in the areas of hydrotechnical structures, open-pit mine drainage, as well as the stability of slopes. The problem also concerns buildings in relation to environmental protection, in waste landfills, sewage treatment plants, etc. Currently, an increasingly serious problem during construction of excavations (below the groundwater table) is drainage of the construction site. Due to the limitations of environmental decisions, the inflow of groundwater into the excavation should be estimated in detail, and then the optimal method of drainage should be selected.

There are many different methods to determine the hydraulic conductivity including field methods (Kozeny, 1953; Cheng \& Chen, 2007; Hussain \& Nabi, 2016), laboratory methods and calculations from empirical formulas (Kozerski, 1977; Twardowski \& Drożdżak, 2006; Idris-Nda, 2013). The most commonly used method of field tests is pumping test, which involves pumping water out of a well to obtain a hydro- 
dynamic reaction of the subsoil. In situ tests based on pumping tests are the most accurate in describing the actual filtration conditions in the subsoil, but due to time-consumption, the cost and scope of implementation (construction of wells and piezometers), they are rarely performed at the stage of geotechnical investigation (Wrzesiński, 2020). On the other hand, laboratory tests for the estimation of permeability are less reliable. In the field of geotechnical tests, the hydraulic conductivity for coarse-grained soils is most often determined using empirical formulas based on the particle size distribution curve. It is justified because the particle size analysis is performed as standard test in most geotechnical investigations and the particle size distribution is the main factor influencing the permeability of coarse soils (Parylak, Zięba, Bułdys \& Witek, 2013). Therefore, this method of determination is widely practiced despite its lower reliability of estimation of the hydraulic conductivity.

There are many empirical formulas for calculating the hydraulic conductivity based on the particle size distribution. They have a limited scope of application and limited accuracy of determinations related to the subjective interpretation of the particle size curve, especially, in the case of sandy soils containing clay or silt admixtures. Empirical formulas can be divided into three groups (Twardowski \& Drożdżak, 2006):

- Group I - formulas that only take into account characteristic grain diameters;

- Group II - formulas taking into account the characteristic grain diameter and porosity of soil;

- Group III - formulas taking into account the granulometric composition and porosity of the soil as well as the physical properties of the filtering water.

The aim of this study was to determine if there is a relationship between hydraulic conductivity and density index and if it is large enough to be used to determine the filtration coefficient by indirect methods (empirical formulas). The value of this index depends among others on grain composition, porosity, grain shape (Parylak et al., 2013). Porosity is one of the important parameters determining the ability of soil to accumulate water. It is also closely related to the density and shape of grains (Zięba, 2016). The impact of the density index and the shape of soil grains (depend- ing from the genesis) on the obtained permeability coefficients are significant for non-cohesive soils from the practical point of view. Results from the literature show that for the same soils but with different density indexes, the permeability coefficient differs even several times (Wrzesiński, 2020). There are formulas in literature, based on porosity and other properties. However, their use requires taking additional samples and conducting laboratory tests, which increase the time of execution and generate additional costs. The density index value is almost always obtained in field tests (dynamic sounding, static sounding) as part of geological or geotechnical investigations.

The purpose of the research presented in the paper is to determine and compare the values of the permeability coefficient in coarse soils determined with use of selected empirical formulas and simple laboratory tests, with focus on the impact of the density index change.

\section{MATERIAL AND METHODS}

The tests were conducted on samples of coarse-grained (non-cohesive) soils from Poland. Sample soils genetically belong to fluvial formations of the Mazovian interglacial and fluvioglacial formations of the Odra glaciation. The hydraulic conductivity of samples was determined by two methods: the first, based on laboratory tests, and the second, using empirical formulas.

The laboratory method of determining the conductivity is based on the principle of measuring the velocity of lowering of the table of water freely flowing out of a tube containing a sample of the examined ground (i.e. the Kaminski tube). The method allows for very simple and quick determination of approximate value of hydraulic conductivity of high permeable soils. The principle of the method is to measure the velocity of lowering of the table of water flowing through the sample of specified height at variable (decreasing) pressure of water column (Myślińska, 1998; Twardowski \& Drożdżak, 2007). The formula for estimating the hydraulic conductivity has the form:

$$
k=\frac{l}{t} \ln \left(1-\frac{s}{H_{0}}\right)
$$


where:

$k-$ hydraulic conductivity [cm],

$t$ - time for the water column to decrease in height [s],

$s-$ reduction of height of the water column [mm, $\mathrm{cm}]$,

$H_{0}$ - initial hydraulic height in the tube $[\mathrm{mm}, \mathrm{cm}]$.

In spite of its simplicity and some limitations, the method has been widely used in practice as a simple method of determining the hydraulic conductivity of soils (Kozerski, 1977). Some studies show that estimated filtration values reflect realistic results from test pumping (Żurek \& Czudec, 2007).

Testing of the hydraulic conductivity was carried out on samples with disturbed structure. The samples were dried in the oven at $105^{\circ} \mathrm{C}$. According to PN-B-04481:1988 standard (Polski Komitet Normalizacyjny [PKN], 1988) the maximum and minimum dry density volume of soil was tested in order to determine the parameters of forming samples at different degrees of compaction. Samples intended for filtration testing were formed dry and then wetted by capillarity. This was done from the bottom so that air could escape from the surface.

For each sample, four filtration tests were performed using the laboratory method for a given compaction level to determine the filtration coefficient at a given density and then the average of these four measurements was taken. The tests were made for four density index levels: loose $-\ln \left(I_{D}=0.30\right)$, medium dense $-\operatorname{szg}\left(I_{D}=0.50\right)$, dense $-\mathrm{zg}\left(I_{D}=0.70\right)$, very dense - bzg $\left(I_{D}=0.90\right)$. In total, 112 filtration tests were carried out. All results were related to temperature $10^{\circ} \mathrm{C}$ using the empirical equation:

$$
k_{10}=\frac{k_{t}}{0.7+0.03 T}
$$

where:

$k_{10}$ - hydraulic conductivity at the water temperature of $10^{\circ} \mathrm{C}\left[\mathrm{m} \cdot \mathrm{s}^{-1}\right]$,

$k_{t}$ - hydraulic conductivity at the temperature $T$, at which the test was conducted $\left[\mathrm{m} \cdot \mathrm{s}^{-1}\right]$,

$T$ - water temperature at the time of testing $\left[{ }^{\circ} \mathrm{C}\right]$.

In aim to determine the hydraulic conductivity based on empirical formulas and to control the grain size distribution of each sample (for which the labora- tory filtration test was carried out), the particle size distribution was established according to PKN-CEN ISO/TS 17892-4:2008 (PKN, 2008). Based on the particle size curve, parameters $d_{10}, d_{17}, d_{50}, d_{60}$ and soil type were determined, where $d_{10}, d_{17}, d_{50}, d_{60}$, are grain sizes [mm] corresponding to $10,17,50$ and $60 \%$ by weight passing through the sieves. The soil type was determined in accordance with PN-B-0248:1986 (PKN, 1986) as well as PN-EN ISO 14688-2:2019 (PKN, 2019). The results (28 tests) are summarized in Table 1.

In order to determine the hydraulic conductivity by the indirect method, some empirical formulas based on studies by Vukovic and Soro (1992) were used. The general form of the formula is expressed as:

$$
K=\left[\frac{g}{v}\right] \cdot[\beta] \cdot[\vartheta(n)] \cdot\left[d_{e}^{2}\right]
$$

where:

$K \quad$ - hydraulic conductivity $\left[\mathrm{cm} \cdot \mathrm{s}^{-1}\right]$,

g - the gravitational constant $\left[\mathrm{cm} \cdot \mathrm{s}^{-2}\right]$,

$v \quad-$ kinematic viscosity, $v=\frac{\mu}{\rho}$, where: $\mu$ - the temperature-dependent dynamic viscosity of water $\left[\mathrm{g} \cdot \mathrm{cm}^{-1} \cdot \mathrm{s}^{-1}\right], \rho-$ the temperature-dependent water density $\left[\mathrm{g} \cdot \mathrm{dm}^{-3}\right]$,

$\beta-$ constant depending on characteristics of the porous medium,

$\vartheta(n)$ - porosity function,

$d_{e} \quad$ - effective grain diameter [cm, mm],

To evaluate the applicability of the empirical formulas for determination of the hydraulic conductivity, calculations of this parameter were carried out using the following five formulas:

1. Hazen (1892) according to Vukovic and Soro (1992) and Devlin (2015)

$$
K=\frac{g}{v} \cdot\left[6 \cdot 10^{-4}\right] \cdot[1+10(n-0.26)] \cdot d_{10}^{2}
$$

Hazen formula is used for uniformly graded sands; however, it could also be used for the range fine sand - gravel, provided the sediment has a uniformity coefficient less than 5 and effective grain size between 0.1 and $3 \mathrm{~mm}$. 
Jaśkiewicz, K., Godlewski, T. (2021). Verification of determination of hydraulic conductivity for coarse soils by empirical formulas based on the density index. Acta Sci. Pol. Architectura, 20 (2), 83-92. doi: 10.22630/ASPA.2021.20.2.17

Table 1. Presentation of grain size distribution characteristic of analysed soil

\begin{tabular}{|c|c|c|c|c|c|c|c|c|c|}
\hline \multirow{2}{*}{ Test } & \multirow{2}{*}{$\begin{array}{c}\text { Soil } \\
\text { sample }\end{array}$} & \multicolumn{2}{|c|}{ Soil type acc. to } & \multirow{2}{*}{$\begin{array}{l}\text { Coefficient } \\
\text { of uniformity } \\
(C U) \\
{[-]}\end{array}$} & \multicolumn{4}{|c|}{$\begin{array}{l}\text { Particle size distribution } \\
{[\text { [mm }]}\end{array}$} & \multirow{2}{*}{$\begin{array}{c}\text { Density index } \\
\qquad\left(I_{D}\right) \\
{[-]}\end{array}$} \\
\hline & & PN-B-0248 & $\begin{array}{c}\text { PN-EN ISO } \\
14688-2\end{array}$ & & $d_{10}$ & $d_{17}$ & $d_{50}$ & $d_{60}$ & \\
\hline 1 & \multirow{4}{*}{1} & Ps & MSa & 2 & 0.20 & 0.26 & 0.38 & 0.42 & 0.90 \\
\hline 2 & & Ps & MSa & 2 & 0.17 & 0.23 & 0.38 & 0.42 & 0.70 \\
\hline 3 & & Ps & $\mathrm{MSa}$ & 2 & 0.23 & 0.27 & 0.39 & 0.43 & 0.50 \\
\hline 4 & & Ps & $\mathrm{MSa}$ & 2 & 0.19 & 0.26 & 0.39 & 0.43 & 0.30 \\
\hline 5 & \multirow{4}{*}{2} & Ps & $\mathrm{MSa}$ & 3 & 0.12 & 0.15 & 0.27 & 0.32 & 0.90 \\
\hline 6 & & Ps & $\mathrm{MSa}$ & 3 & 0.12 & 0.15 & 0.27 & 0.32 & 0.70 \\
\hline 7 & & Ps & MSa & 3 & 0.12 & 0.14 & 0.29 & 0.34 & 0.50 \\
\hline 8 & & Ps & MSa & 3 & 0.12 & 0.15 & 0.28 & 0.34 & 0.30 \\
\hline 9 & \multirow{4}{*}{3} & Ps & $\mathrm{MSa}$ & 3 & 0.10 & 0.13 & 0.25 & 0.30 & 0.90 \\
\hline 10 & & Ps & $\mathrm{MSa}$ & 3 & 0.12 & 0.15 & 0.28 & 0.33 & 0.70 \\
\hline 11 & & Ps & $\mathrm{MSa}$ & 3 & 0.12 & 0.14 & 0.26 & 0.32 & 0.50 \\
\hline 12 & & Ps & $\mathrm{MSa}$ & 3 & 0.13 & 0.16 & 0.31 & 0.36 & 0.30 \\
\hline 13 & \multirow{4}{*}{4} & Ps & $\mathrm{MSa}$ & 3 & 0.12 & 0.15 & 0.31 & 0.37 & 0.90 \\
\hline 14 & & Ps & $\mathrm{MSa}$ & 3 & 0.11 & 0.14 & 0.29 & 0.35 & 0.70 \\
\hline 15 & & Ps & $\mathrm{MSa}$ & 3 & 0.12 & 0.15 & 0.30 & 0.36 & 0.50 \\
\hline 16 & & Ps & $\mathrm{MSa}$ & 3 & 0.11 & 0.14 & 0.29 & 0.34 & 0.30 \\
\hline 17 & \multirow{4}{*}{5} & Ps & $\mathrm{MSa}$ & 3 & 0.12 & 0.15 & 0.31 & 0.36 & 0.90 \\
\hline 18 & & Ps & $\mathrm{MSa}$ & 3 & 0.12 & 0.16 & 0.32 & 0.37 & 0.70 \\
\hline 19 & & Ps & $\mathrm{MSa}$ & 3 & 0.12 & 0.16 & 0.32 & 0.37 & 0.50 \\
\hline 20 & & Ps & $\mathrm{MSa}$ & 3 & 0.13 & 0.16 & 0.31 & 0.37 & 0.30 \\
\hline 21 & \multirow{4}{*}{6} & $\operatorname{Pr}$ & $\mathrm{CSa}$ & 5 & 0.19 & 0.27 & 0.78 & 0.93 & 0.90 \\
\hline 22 & & $\operatorname{Pr}$ & $\mathrm{CSa}$ & 5 & 0.19 & 0.27 & 0.78 & 0.94 & 0.70 \\
\hline 23 & & $\operatorname{Pr}$ & $\mathrm{CSa}$ & 5 & 0.18 & 0.24 & 0.75 & 0.93 & 0.50 \\
\hline 24 & & $\operatorname{Pr}$ & $\mathrm{CSa}$ & 5 & 0.19 & 0.27 & 0.78 & 0.93 & 0.30 \\
\hline 25 & \multirow{4}{*}{7} & Po & $\mathrm{grCSa}$ & 2 & 0.51 & 0.57 & 0.85 & 0.94 & 0.90 \\
\hline 26 & & Po & grCSa & 2 & 0.47 & 0.55 & 0.85 & 0.94 & 0.70 \\
\hline 27 & & Po & grCSa & 2 & 0.49 & 0.57 & 0.88 & 0.98 & 0.50 \\
\hline 28 & & Po & $\mathrm{grCSa}$ & 2 & 0.50 & 0.57 & 0.87 & 0.97 & 0.30 \\
\hline
\end{tabular}

Ps (MSa) - medium sand; $\operatorname{Pr}(\mathrm{CSa})$ - coarse sand; Po (grCSa) - coarse sand with gravel. 
2. Sauerbrei (1932) according to Vukovic and Soro (1992) and Devlin (2015)

$$
K=\frac{g}{v} \cdot\left[\left(3.75 \cdot 10^{-5}\right) \tau\right] \cdot\left[\frac{n^{2}}{(1-n)^{2}}\right] \cdot d_{17}^{2}
$$

where:

$\tau \cong 1.093 \cdot 10^{-4} T^{2}+2.102 \cdot 10^{-2}+0.5889$,

$T$ - temperature of water $\left[{ }^{\circ} \mathrm{C}\right]$.

3. Kozeny-Carman (1953) according to Vukovic and Soro (1992) and Devlin (2015)

$$
K=\frac{g}{v} \cdot\left[8.3 \cdot 10^{-3}\right] \cdot\left[\frac{n^{3}}{(1-n)^{2}}\right] \cdot d_{10}^{2}
$$

The Kozeny-Carman formula is not appropriate for soils with effective size above $3 \mathrm{~mm}$ or for clayey soils (Carrier, 2003).

4. Zamarin (1928) according to Vukovic and Soro (1992) and Devlin (2015)

$$
K=\frac{g}{v} \cdot\left[8.64 \cdot 10^{-3}\right] \cdot\left[\frac{n^{3}}{(1-n)^{2}} C_{n}\right] \cdot\left[\frac{1}{\sum_{i=1}^{m} \Delta g_{i} \frac{\ln \left(\frac{d_{i}^{g}}{d_{i}^{d}}\right)}{d_{i}^{g}-d_{i}^{d}}}\right]^{2}
$$

where:

$C_{n}$ - factor depending on the porosity, $C_{n}=(1,275-1.5 n)^{2}$,

$\Delta g_{i}$ - the fraction of mass that passes between sieves $i$ and $i+1$ where $i$ is the smaller sieve,

$d_{i}^{g}-$ the maximum grain diameter in fraction $i$,

$d_{i}^{d}-$ the minimum grain diameter in fraction $i$.

The formula is applicable for large-grained sands with no fractions having $d<0.00025 \mathrm{~mm}$. It can be used for fine and medium-grained sands.
5. Chapuis (2004) according to Vukovic and Soro (1992) and Devlin (2015)

$$
K=\left[10^{1.291 \xi-0.6435}\right] \cdot\left[d_{10}^{0.510^{(0.5504-0.2937)}}\right]^{2}
$$

$$
\xi=\frac{n}{1-n}
$$

The Chapuis formula is applicable for $0.3<n<0.7$, $0.10<d_{10}<2.0 \mathrm{~mm}, 2<C U<12, d_{10} / d_{5}<1.4$.

\section{RESULTS AND DISCUSSSION}

Based on the results obtained from particle size distribution (Table 1), the soils were divided into the following groups:

A. Medium sand $-\mathrm{MSa}(\mathrm{Ps}): \mathrm{A}_{1}-C U=2$ (Sample 1) and $\mathrm{A}_{2}-C U=3$ (Samples 2, 3, 4, 5).

B. Coarse sand - CSa (Pr); $C U=5$ (Sample 6).

C. Coarse sand with gravel $-\operatorname{grCSa}(\mathrm{Po}) ; C U=$ $=2$ (Sample 7).

The division criterion was the soil type, the coefficient of uniformity $(C U)$ and value of effective grain diameter. The change in the hydraulic conductivity determined by a laboratory method was observed depending on the density index for each of the soil groups. In the case of laboratory tests for coarse-grained soils of loose density (density index $I_{D}=0.3$ ) during the water permeability determination with use of a so-called the Kaminski tube, the consolidation of samples during the filtration test was observed, which resulted in a change of the compaction state from loose to medium dense (Fig. 1). The cause of this phenomenon may arise from the temporary induction of negative pore pressure during saturation of the dry-formed sample.

The determination of the hydraulic conductivity by the indirect method (empirical formulas) was performed for each sample at different porosity values corresponding to the density index at which the laboratory tests were performed. The results of calculations with these formulas, for individual soil samples and laboratory tests, are presented in Table 2. 


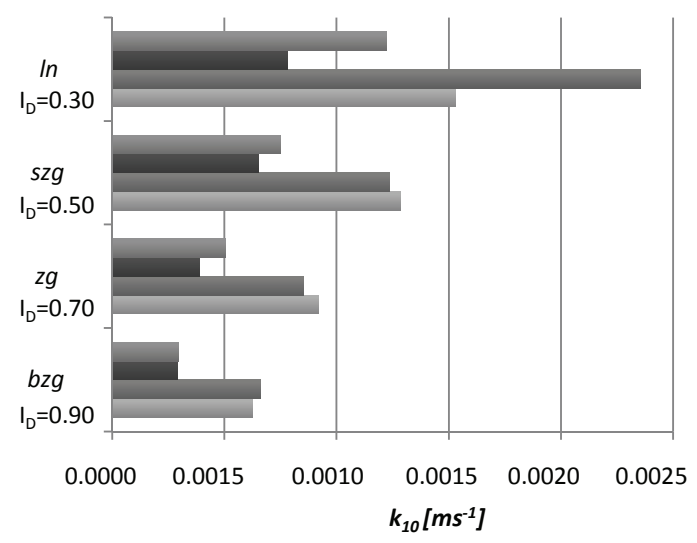

Ps (MSa)

$\mathrm{CU}=3$

Sample No. 5

- Sample No. 4

- Sample No. 3

nample No. 2

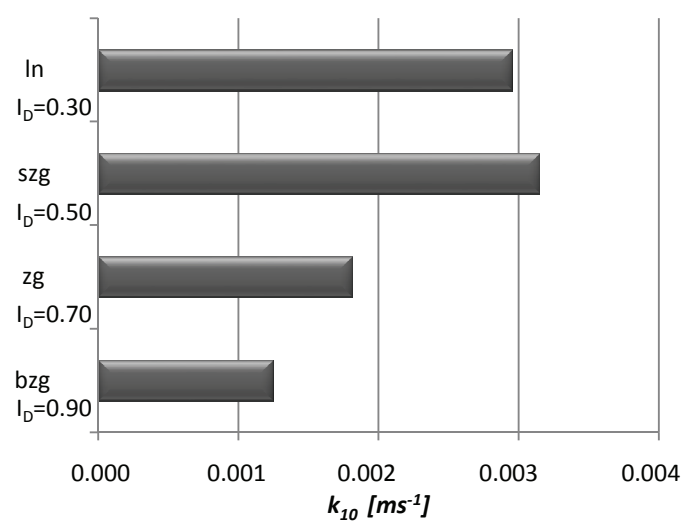

Ps (MSa)

$\mathrm{Cu}=2$

$\square$ Sample No. 1

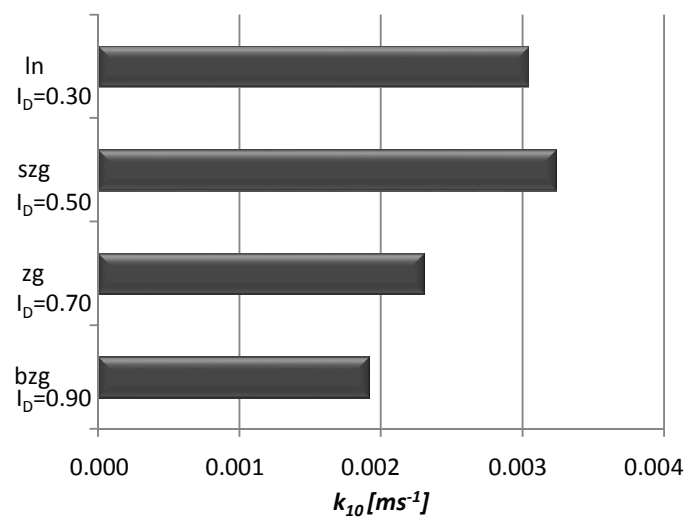

$\operatorname{Pr}(\mathrm{CSa})$

Sample No. 6

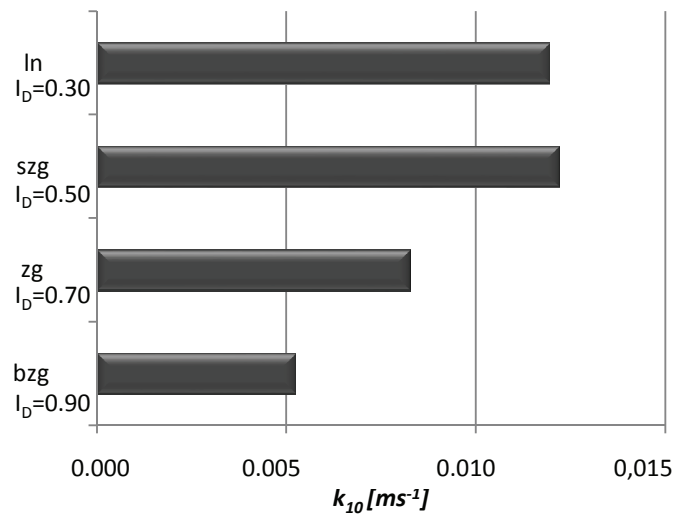

Po (grCSa)

a Sample No. 7 Fig. 1. Changes in the hydraulic conductivity $\left(k_{10}\right)$ laboratory tests for Ps (MSa) - medium sand; $\operatorname{Pr}(\mathrm{CSa})$ - coarse sand; Po (grCSa) - coarse sand with gravel (average of four determinations: ln - loose; szg - medium dense; zg - dense; bzg - very dense) depending on the density index $\left(I_{D}\right)$ 
莺志芯

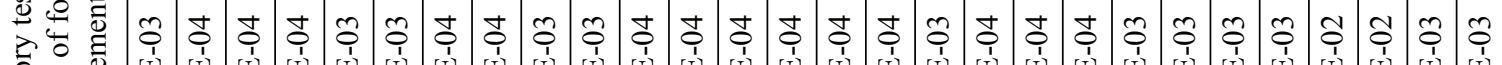

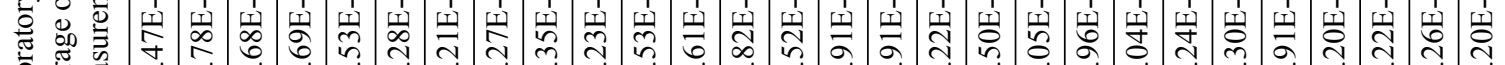
卷

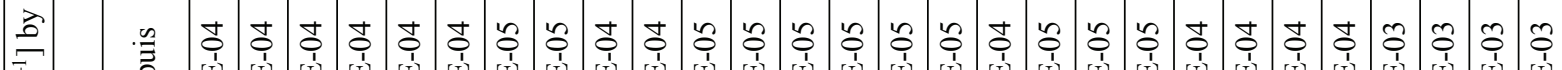

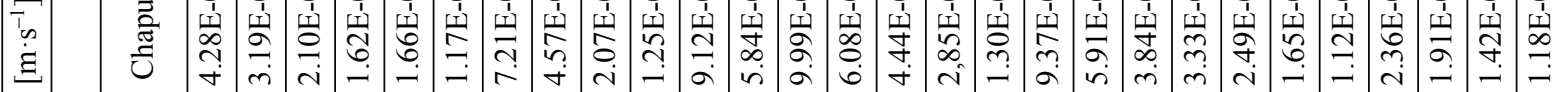

突

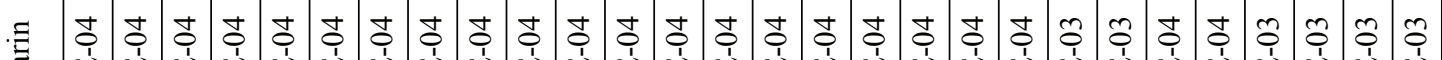

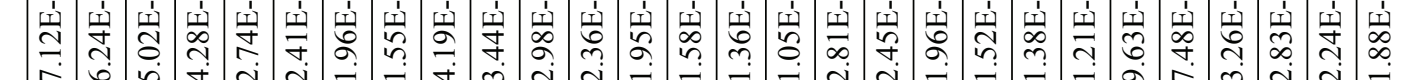
N $\vec{r}$ bु

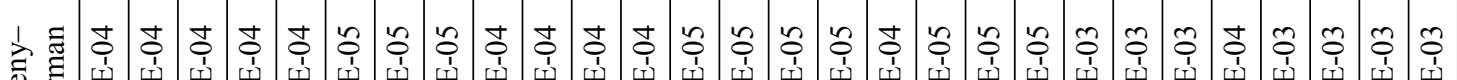

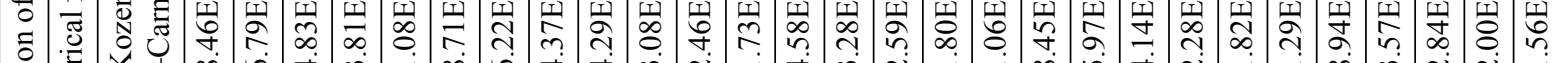

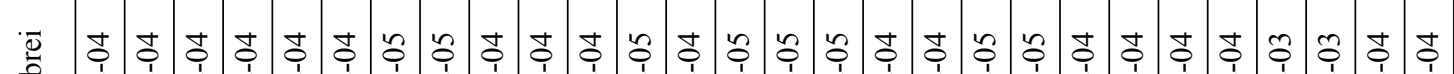

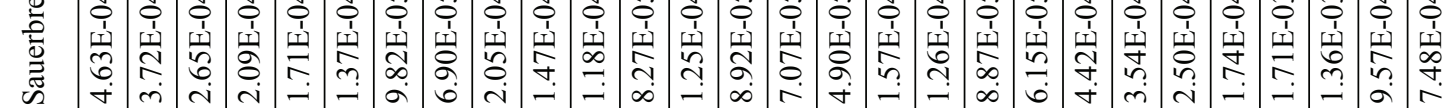

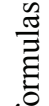

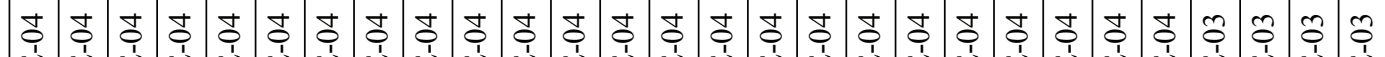

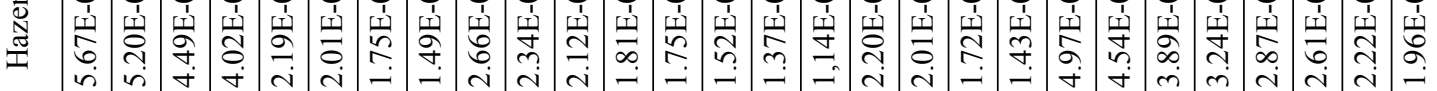

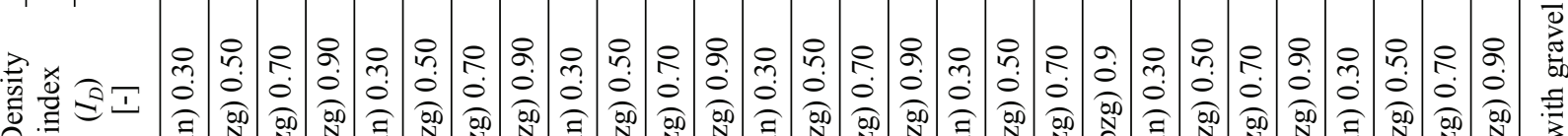

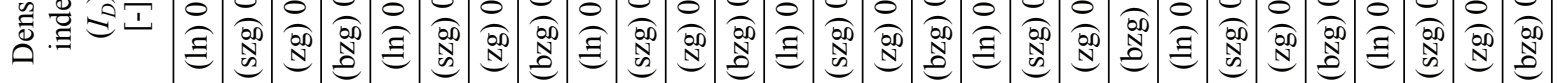

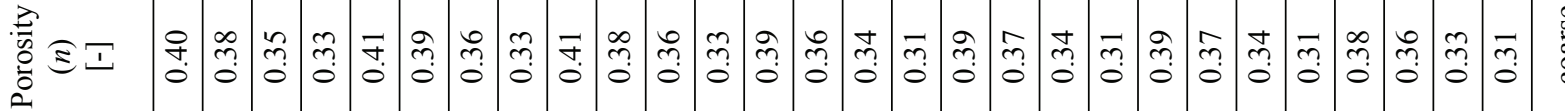

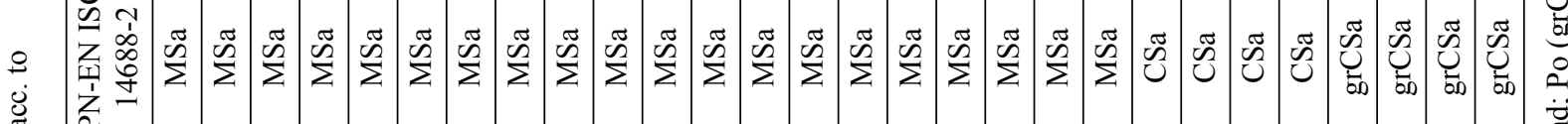

范

鱿

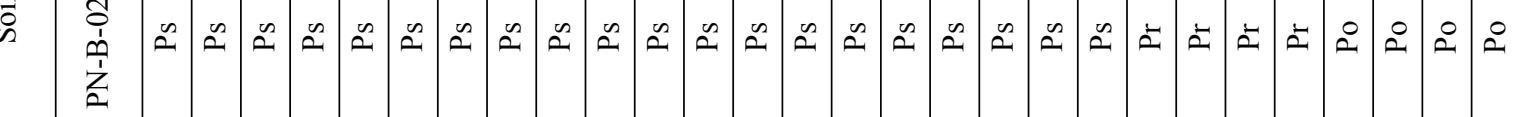

冚

:

"न

ठี

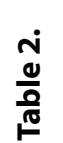

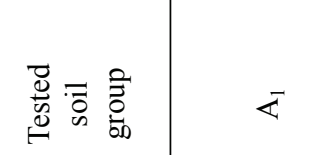

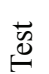

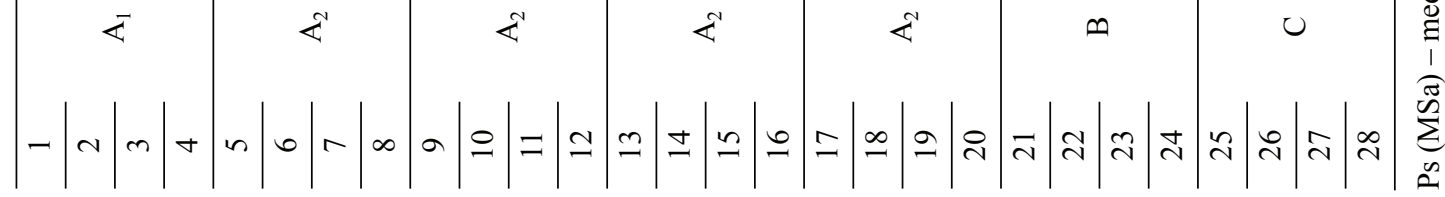


Data presented in Figure 1 show clear relation between the changes in the hydraulic conductivity $(k)$ and effective pore diameter caused by the increase in the density index $\left(I_{D}\right)$. This points at the need of taking the state of the soil (density) into account. This relationship is visible regardless of the grain size and type of material. Generally, lower permeability coefficients were obtained in soils characterized by a higher density index. It should be noted that the value of the permeability coefficient is influenced by the shape of soil particles and their mutual arrangement (Parylak et al., 2013; Zięba, 2016; Shen, Zhu \& Gu, 2019; Wrzesiński, 2020). This effect can be ignored in this study, since all sands had the same origin - they are alluvial soils.

When analysing the results given in Table 2, formulas with a better and worse match to the results obtained from direct measurements can be indicated. The best representation for non-cohesive soils of group $\mathrm{A}_{1}$ was obtained with the Chapuis formula, and for group $\mathrm{A}_{2}$ with the Zamarin formula. For soils of $\mathrm{B}$ and $\mathrm{C}$ groups, the best results in comparison with laboratory tests were obtained by Kozeny-Carman formula. The Hazen formula gave relatively good hydraulic conductivity values for each group relative to the labo- ratory tests. This comparison indicates the need for individual evaluation of reliability of the formulas in the assessment of the filtration considering the material type. An attempt was made to verify the hydraulic conductivity determined according to the Hazen formula (most commonly used in design practice) taking into account density index (corresponding to porosity) for each tested soils (Fig. 2). For the Hazen equation, the filtration coefficients obtained are of lower order of magnitude than the laboratory test results, depending on the density parameter.

\section{CONCLUSIONS}

Laboratory methods were used to evaluate the hydraulic conductivity $(k)$, which is a basic hydrogeological parameter determining the ability of soil to transport water, and confronted with the values obtained from empirical formulas for soils characterized by four different density indexes. The results of the filtration coefficient calculations based on empirical formulae are inaccurate and highly differentiated (in described cases from four to six times), which undermines their reliability and excludes the possibility of using this method in well-understood engineering practice. soil groups $\mathrm{A}_{1}, \mathrm{~A}_{2}$, B

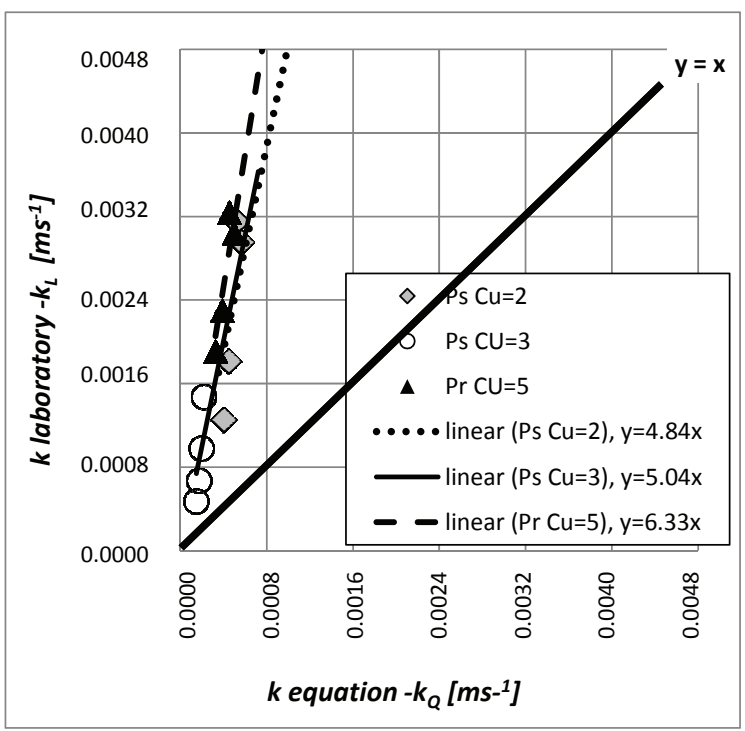

soil group $\mathrm{C}$

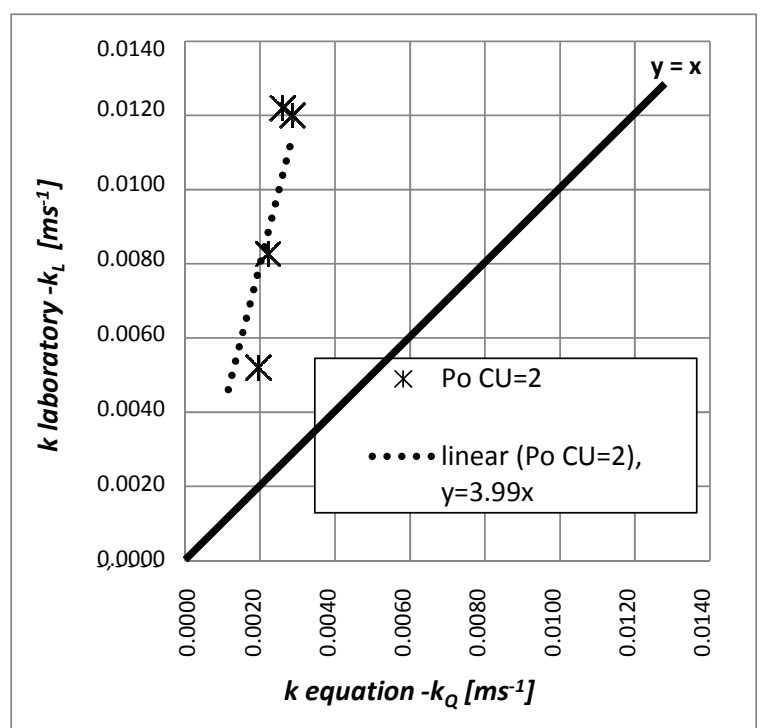

Fig. 2. Relations between hydraulic conductivity obtained from empirical formula $\left(k_{Q}\right)$ and in laboratory tests $\left(k_{L}\right)$ of soil groups 
In the case of empirical formulas, a randomly selected soil sample has been tested and the result depends in principle only on the particle size of the soil. Laboratory methods almost always generate filtration factor values lower than those obtained by empirical formulas. The empirical formulas used often give permeability coefficient values several times smaller or larger than the actual values observed in the field. Empirical formulas give only approximate values of the permeability coefficient, because they do not embrace real in-situ conditions.

The results, as an attempt to find relationship between filtration and density index, are promising; however, the research is preliminary in nature. The proposal for verification of the formulas, taking into account the degree of soil compaction, will be extended to other methods of testing the hydraulic conductivity, e.g. with a constant head permeameter.

\section{Authors' contributions}

Conceptualization: T.G. and K.J.; methodology: K.J.; validation: T.G. and K.J.; formal analysis: T.G. and K.J.; investigation: K.J.; resources: K.J.; data curation: K.J.; writing - original draft preparation: K.J.; writing - review and editing: T.G. and K.J.; visualization: K.J.; supervision: T.G.; project administration: T.G.

All authors have read and agreed to the published version of the manuscript.

\section{REFERENCES}

Chapuis, R. P. (2004). Predicting the saturated hydraulic conductivity of sand and gravel using effective diameter and void ratio. Canadian Geotechnical Journal, 41, 787-795.

Cheng, C. \& Chen, X. (2007). Evaluation of Methods for Determination of Hydraulic Properties in an Aquifer-Aquitard System Hydrologically Connected to River. Hydrogeology Journal, 15, 669-678. http://doi. org/10.1007/s10040-006-0135-z

Devlin, J. F. (2015). HydrogeoSieveXL: an Excel-based tool to estimate hydraulic conductivity from grain size analysis. Hydrogeology Journal. http://doi.org/10.1007/ s10040-015-1255-0

Hazen, A. (1892). Some physical properties of sands and gravels, with special reference to their use in filtration. In 24th Annual Report of the State Board of Health of
Massachusetts (pp. 539-556). Boston: State Board of Health of Massachusetts.

Head, K. \& Epps, R. (2011). Manual of soil laboratory testing. Vol. 2. Permeability, shear strength and compressibility test. Dunbeath Mill: Whittles Publishing.

Hussain, F. \& Nabi, G. (2016). Empirical Formulae Evaluation for Hydraulic Conductivity Determination Based on Grain Size Analysis. Pyrex Journal of Research in Environmental Studies, 3 (3), 26-32.

Idris-Nda, A. (2013). Estimating Aquifer Hydraulic Properties in Bida Basin, Central Nigeria Using Empirical Methods. Earth Science Research, 2(1). http://doi. org/10.5539/esr.v2n1p209

Jiang, R., Li, T., Liu, D., Fu, Q., Hou, R., Li, Q., Cui, S. \& Li, M. (2021). Soil infiltration characteristics and pore distribution under freezing-thawing conditions. Cryosphere, 15 (4), 2133-2146. http://doi.org/10.5194/ tc-15-2133-2021

Kozeny, J. (1953). Das Wasser im Boden. Grundwasserbewegung. In J. Kozeny (Ed.), Hydraulik (pp. 380-445). Vienna: Springer.

Kozerski, B. (1977). Zasady obliczeń hydrogeologicznych ujęć wód podziemnych. Wytyczne określania współczynnika filtracji metodami pośrednimi i laboratoryjnymi. Warszawa: Wydawnictwa Geologiczne.

Myślińska, E. (1998). Laboratoryjne badania gruntów. Warszawa: Wydawnictwo Naukowe PWN.

Parylak, K., Zięba, Z., Bułdys, A. \& Witek, K. (2013). Weryfikacja wyznaczania współczynnika filtracji gruntów niespoistych za pomocą wzorów empirycznych w ujęciu ich mikrostruktury. Acta Sci. Pol. Architectura, 12 (2), 43-51.

Polski Komitet Normalizacyjny [PKN] (1986). Grunty budowlane. Określenia symbole podziat $i$ opis gruntów (PN-B-0248:1986). Warszawa: Polski Komitet Normalizacyjny.

Polski Komitet Normalizacyjny [PKN] (1988). Grunty budowlane. Badania próbek gruntu (PN-B-04481:1988). Warszawa: Polski Komitet Normalizacyjny.

Polski Komitet Normalizacyjny [PKN] (2008). Badania geotechniczne. Badania laboratoryjne gruntów. Część 4: Oznaczanie składu granulometrycznego (PKN-CEN ISO/TS 17892-4:2008). Warszawa: Polski Komitet Normalizacyjny.

Polski Komitet Normalizacyjny [PKN] (2019). Badania geotechniczne. Oznaczanie i klasyfikowanie gruntów. Część 2: Zasady klasyfikowania (PN-EN ISO 14688-2: 2019). Warszawa: Polski Komitet Normalizacyjny.

Shen, C., Zhu, J. \& Gu, W. (2019). Prediction Method for Hydraulic Conductivity considering the Effect of Sizes 
of Ellipsoid Soil Particles from the Microscopic Perspective. Advances in Civil Engineering, 7213094. http://doi. org/10.1155/2019/7213094

Twardowski, K. \& Drożdżak, R. (2006). Pośrednie metody oceny właściwości filtracyjnych gruntów. Wiertnictwo Nafta Gaz, 23 (1), 477-486.

Twardowski, K. \& Drożdżak, R. (2007). Uwarunkowania dotyczące laboratoryjnych metod oznaczania wodoprzepuszczalności gruntów. Wiertnictwo Nafta Gaz, 24 (1), 565-574.

Vukovic, M. \& Soro, A. (1992). Determination of hydraulic conductivity of porous media from grain-size composition [trans. from Serbo-Croation by Dubravka Miladinov]. Littleton, CO: Water Resources Publications.

Wiłun, Z. (1982). Zarys geotechniki. Warszawa: Wydawnictwo Komunikacji i Łączności.

Wrzesiński, G. (2020). Permeability coefficient tests in non-cohesive soils. Przeglad Naukowy. Inżynieria i Ksztattowanie Środowiska - Scientific Review. Engineering and Environmental Sciences, 29 (1), 72-80. http://doi. org/10.22630/PNIKS.2020.29.1.7
Zamarin, J. A. (1928). Raschet dvizheniya gruntovykh vod [Calculation of ground-water flow]. Moskva: Izdatelstvo I.V.Kh.

Zięba, Z. (2016). Influence of soil particle shape on saturated hydraulic conductivity, Journal of Hydrology and Hydromechanics, 65 (1), 80-87. http://doi.org/10.1515/ johh-2016-0054

Żurek, A. \& Czudec, Ł. (2007). Pionowa zmienność prametrów hydrogeologicznych w czwartorzędowym zbiorniku wód podziemnych (GZWP 450 - Dolina rzeki Wisły) na przykładzie profilu studni badawczej z poletka doświadczalnego AGH [The vertical variability of the hydrogeological parameters in the quaternary groundwater basin (MGWB 450 - the Vistula river valley) illustrated by the example of the AGH University of Science and Technology Experimental Field Research Well Profile]. In A. Szczepański, E. Kmiecik \& A. Żurek (Eds.), Współczesne problemy hydrogeologii. Vol. 13. Part 2 (pp. 389-399). Kraków: Wydział Geologii, Geofizyki i Ochrony Środowiska AGH.

\section{WERYFIKACJA WYZNACZANIA WSPÓŁCZYNNIKA FILTRACJI GRUNTÓW GRUBOZIARNISTYCH ZA POMOCĄ WZORÓW EMPIRYCZNYCH Z UWZGLĘDNIENIEM STOPNIA ZAGĘSZCZENIA}

\section{STRESZCZENIE}

W pracy zbadano przydatność wzorów empirycznych do oceny współczynnika filtracji gruntów niespoistych z uwzględnieniem ich zagęszczenia. Wzory empiryczne są często stosowane w praktyce do szybkiego i taniego wyznaczania współczynnika filtracji. Weryfikację obliczeń współczynnika filtracji przeprowadzono dla pięciu wzorów uwzględniających charakterystyczne średnice ziarna oraz porowatość. Otrzymane wyniki porównano z wynikami badań laboratoryjnych wykonanych na próbkach gruntów o takich samych wskaźnikach porowatości (przy różnych stopniach zagęszczenia), jakie przyjmowano w metodzie obliczeniowej. Zaproponowano formułę empiryczną pozwalającą skorygować współczynnik filtracji gruntów uzyskanych na podstawie wzoru Hazena, uwzględniając stopień zagęszczenia danego gruntu.

Słowa kluczowe: filtracja, współczynnik filtracji, wzory empiryczne, stopień zagęszczenia 